\title{
Het hoger beroep inzake het schietincident in Alphen aan den Rijn: hoe gerechtigheid zegevierde, en de geest in de fles bleef
}

\author{
$M r . K . L . M a e s^{*}$
}

\begin{abstract}
1. Inleiding
Nadat de aansprakelijkheid van de politie voor het schietincident in Alphen aan den Rijn in 2015 op relativiteitsgronden strandde bij de Rechtbank Den Haag, ${ }^{1}$ zien de slachtoffers van het schietincident door de recente uitspraak van het Gerechtshof Den Haag toch een gedeelte van de geleden schade vergoed. ${ }^{2}$ Het hof vernietigt het vonnis van de rechtbank en houdt de politie aansprakelijk voor de door de slachtoffers en nabestaanden geleden letsel- en overlijdensschade, vanwege het ten onrechte verstrekken van de wapenvergunning aan Tristan van der V. (hierna: Tristan). Na een reeks afwijzende uitspraken in de jaren daarvoor is de uitspraak van het hof de eerste waarin aansprakelijkheid naar aanleiding van het schietincident in Alphen aan den Rijn wordt aanvaard. In 2017 had immers ook een procedure tegen de ouders van Tristan, alhoewel ingesteld door een andere groep slachtoffers, niet mogen baten. ${ }^{3}$ Evenmin werd de door hen aangesproken aansprakelijkheidsverzekeraar van de ouders van Tristan door de rechtbank tot uitkering van de geleden schade gehouden. ${ }^{4}$
\end{abstract}

\footnotetext{
Mr. K.L. Maes is advocaat bij Van Benthem \& Keulen te Utrecht en als buitenpromovenda verbonden aan het Utrecht Centre for Accountability and Liability Law (UCALL) van de Universiteit Utrecht. Zij werkt aan een proefschrift over de zorgplicht van secundaire, private partijen jegens bezoekers van openbare ruimten.

1. Rb. Den Haag 4 februari 2015, ECLI:NL:RBDHA:2015:1061.

2. Hof Den Haag 27 maart 2018, ECLI:NL:GHDHA:2018:541.

3. De rechtbank oordeelt - kort gezegd - dat concrete kennis van het uiteindelijk verwezenlijkte gevaar aan de zijde van de ouders ontbreekt en dat deze wetenschap evenmin aan de ouders kan worden toegerekend. De ouders treft, aldus de rechtbank, 'geen enkel verwijt'. Zie voor de uitspraak waarin de aansprakelijkheid van de ouders wordt afgewezen: $\mathrm{Rb}$. Den Haag 4 juni 2017, ECLI:NL:RBDHA:2017:6371 en een uitvoerige analyse daarvan eerder: K.L. Maes, Over de zoektocht naar en de grenzen van secundaire aansprakelijkheid na het schietincident in Alphen aan den Rijn, TVP 2017, afl. 4, p. 120-128 (hierna: Maes 2017a).

4. Rb. Den Haag 17 januari 2018, ECLI:NL:RBDHA:2018:358. De rechtbank oordeelt dat de verzekeraar erin is geslaagd om het eerder aangenomen bewijsvermoeden dat Tristan was meeverzekerd onder de aansprakelijkheidsverzekeraar van zijn ouders, te ontzenuwen, en aldus niet verplicht kan worden dekking te verlenen onder deze verzekering.
}

Wat brengt het hof (wel) tot de (secundaire) ansprakelijkheid van de politie, daar waar de rechtbank deze aansprakelijkheid eerder integraal van de hand wees? Neemt het hof met zijn arrest de eerdere kritiek op de uitspraak van de rechtbank weg? En in het verlengde daarvan: in hoeverre valt de door het hof gemaakte tweedeling in voor vergoeding in aanmerking komende schades - wel vergoeding van letsel- en overlijdensschade, geen vergoeding van andere (vermogens)schade - te rechtvaardigen in het licht van eerdere jurisprudentie en literatuur?

In het onderhavige artikel poog ik deze vragen te beantwoorden door de voornoemde uitspraak van het Gerechtshof Den Haag nader onder de loep te nemen. Daartoe schets ik de relevante feiten van deze zaak (par. 2), de vorderingen en de uitspraak in eerste aanleg (par. 3) en in hoger beroep (par. 4). Vervolgens kom ik tot een analyse van de beide uitspraken, bezien in het licht van de (juridisch-dogmatische) kritiek waarmee het vonnis in eerste aanleg is ontvangen, evenals de daaraan verbonden secundaire aansprakelijkheidsproblematiek. Daarbij maak ik onderscheid tussen de oordelen in eerste aanleg en in hoger beroep omtrent de relativiteit (par. 5) en de voor vergoeding in aanmerking komende schades (par. 6). Ik besluit met een conclusie (par. 7).

\section{De feiten en omstandigheden}

\subsection{Het schietincident en wat daaraan voorafging}

Op zaterdag 9 april 2011 opende de 24-jarige Tristan rond het middaguur in en nabij het winkelcentrum De Ridderhof te Alphen aan den Rijn het vuur op tientallen bezoekers en winkelmedewerkers. Als gevolg daarvan overleden zes mensen en raakten in elk geval zestien mensen gewond. Tristan beroofde zichzelf vrijwel direct na het schietincident van het leven. De voornoemde gebeurtenissen zullen in het navolgende worden aangeduid als 'het schietincident'.

Tristan kampte de jaren voor het schietincident met diverse psychische problemen. Voor de onderhavige procedure tegen 
de politie is met name van belang dat Tristan in september 2006 - een kleine vijf jaar voor het schietincident - na een 112-melding van zijn vader werd opgenomen op de gesloten afdeling van de GGZ Rivierduinen. Aanleiding voor de melding en de uiteindelijke opname was een verontrustend smsbericht van een vriend van Tristan en de vondst van een schrift, waarin Tristan een scenario van een suïcide met een vuurwapen beschreef. De politie had na de 112-melding assistentie verleend bij het van huis ophalen en vervoeren van Tristan naar de instelling waar hij werd opgenomen, en had daarvan een mutatie in het politiesysteem gemaakt (hierna: de BOPZ-mutatie). In de BOPZ-mutatie werd onder meer opgemerkt:

'Belt [x49] van de GGZ Crisisdienst dat ze om 11.15 uur naar genoemd adres gaan om [V.] Dhr vd met een IBS ( $\mathrm{Rb}$ : inbewaringstelling) op te nemen. [V.] is suïcidaal. De ouders hadden contact opgenomen met de crisisdienst toen zij brieven en een schrift hadden [ge]vonden waarin stond dat $[\mathrm{V}$.$] zichzelf van het leven zou gaan beroven (in$ het schrift stond de code van zijn bankpas en hoe hij zijn begrafenis wilde hebben. Vader wist dat [V.] as dinsdag naar de schietvereniging zou gaan als introducé en was nu bang dat $[\mathrm{V}$.$] dinsdag zelfmoord zou gaan plegen.'$

Na deze opname werd Tristan onder de zogenoemde vrijwillige ambulante behandeling van GGZ Rivierduinen gesteld, in welk kader Tristan medicatie kreeg. Nadat Tristan in augustus 2008 een overdosis slaapmiddelen nam, werd hij opnieuw in het ziekenhuis opgenomen.

\subsection{De aanvragen en de verstrekking van het wapenverlof}

Parallel aan deze en andere problematiek - op onder meer het werk en vanwege 'foute vrienden' van Tristan ${ }^{5}$ - groeide de wens van Tristan om (net als zijn vader) over een wapenvergunning te beschikken. Reeds op 1 augustus 2005, en dus vóór de in paragraaf 2.1 omschreven opnamen, had Tristan bij de korpschef van de politie een aanvraag voor een wapenverlof ingediend. Deze aanvraag werd door de korpschef afgewezen, nu uit de politiesystemen een overtreding van de Wet wapens en munitie (hierna: WWM) volgde. Het ging hier om het voorhanden hebben van een luchtbuks, waarmee onder meer op een auto en - na bedreiging - ook op een persoon geschoten was. In het weigeringsbesluit werd dan ook overwogen dat Tristan derhalve 'geen vuurwapens en/of munitie kunnen worden toevertrouwd'.

Tristan werd in 2007 desondanks (opnieuw) lid van een schietvereniging. Op 11 oktober 2008 - en dus na de opnamen en de BOPZ-mutatie - diende Tristan wederom een aanvraag voor een wapenverlof bij de korpschef in. Zijn tweede aanvraag bleek wel succesvol te zijn: na controle van de opbergkluizen voor de wapens en munitie in het huis van (de ouders van) Tristan, verleende de politie op 10 november 2008 het wapenverlof aan Tristan, inclusief het verlof voor het voorhanden hebben en het vervoeren van genoemde vuurwapens en bijbehorende munitie.

Voor de onderhavige uitspraak is van belang dat de medewerker die de tweede verlofaanvraag behandelde, een uittreksel uit de justitiële documentatie had betrokken (waaruit bleek dat Tristan in 2002 vuurwerk buiten de toegestane periode had afgestoken en in 2007 een snelheidsovertreding had begaan), evenals de voornoemde incidenten met de luchtbuks. De medewerker was echter niet op de hoogte van de eerste aanvraag en de daarop volgende weigering tot het verlenen van het wapenverlof aan Tristan in 2005. Evenmin werd de BOPZ-mutatie betrokken bij de beoordeling van de tweede aanvraag voor een wapenverlof.

Het wapenverlof van Tristan werd na de verlening in 2008 door de politie op 9 november 2009 en op 16 november 2010 namens de korpschef telkens verlengd met de duur van één jaar. In 2010 en 2011 schafte Tristan een veelvoud aan wapens, munitie en aanverwante artikelen aan, waarmee hij uiteindelijk op 9 april 2011 in het winkelcentrum De Ridderhof het vuur opende.

\section{De uitspraak van de Rechtbank Den Haag}

\subsection{De procespartijen en standpunten in eerste aanleg}

Eisers in deze procedure zijn slachtoffers en nabestaanden van slachtoffers van het schietincident, ooggetuigen en winkeliers van wie eigendommen ten tijde van het schietincident zijn beschadigd. Eisers claimen vergoeding van de door hen geleden personenschade, zaakschade en/of zuivere vermogensschade. Gedaagde is de Politieregio Hollands Midden (PHM, hier-

5. Voor een meer volledige uiteenzetting van de achtergrond en de geschiedenis aan opnames, de problemen waar de ouders en omgeving mee worstelden en de depressies waar Tristan onder gebukt ging, verwijs ik naar Maes 2017a, p. 120-121. 
na: de politie), welke partij ik beschouw als de secundaire partij. ${ }^{6}$

Voor wat betreft het onderscheid tussen de primaire en de secundaire partij geldt dat ik met de primaire partij doel op de directe veroorzaker van de schade - de partij die het risico direct in het leven heeft geroepen - en daarmee doorgaans de meest gerede partij voor het slachtoffer om in rechte aan te spreken. In de onderhavige zaak beschouw ik Tristan dan ook als de primaire partij. Een secundaire partij (in casu aldus de politie) wordt in de kern verweten het schadeveroorzakende handelen van de primaire partij (het schietincident) niet voorkomen te hebben. Door het (vermeend) gebrekkige toezicht zou de secundaire partij de primaire partij de ruimte en mogelijkheid hebben geboden zich (opzettelijk of onopzettelijk) 'schadeveroorzakend' te gaan gedragen. Met de secundair aangesproken partij doel ik dan ook op de partij die tekort is geschoten in het treffen van voorzorgsmaatregelen of het houden van toezicht teneinde het handelen van de primaire partij te voorkomen, en daarom nalatig handelen kan worden verweten. Het gaat in secundaire aansprakelijkheidsprocedures aldus om zelfstandig te maken verwijten aan het adres van de 'toezichthoudende' partij (en daarmee dus te onderscheiden van risicoaansprakelijkheden). Bedacht dient te worden, tot slot, dat het bij het onderscheid tussen primaire en secundaire partijen gaat om een feitelijk onderscheid (waarin geen causaliteits- of normatief oordeel besloten ligt): welke partij haalde

6. Zie over de aansprakelijkheid van secundaire partijen, al dan niet anders gedefinieerd als 'de secundaire dader', 'de afgeleide partij' of de 'zijdelingse laedens', en de in dat kader rijzende aansprakelijkheidsvragen W.H. van Boom, Aansprakelijkheid naar rato van het veroorzakingsaandeel, in: W.H. van Boom e.a. (red.), Tussen alles of niets, Deventer: W.E.J. Tjeenk Willink 1997, p. 139 e.v.; W.H. van Boom \& I. Giesen, Civielrechtelijke overheidsaansprakelijkheid voor het niet voorkomen van gezondheidsschade door rampen, NJB 2001, p. 1675 e.v.; T. Hartlief \& R.J. Tjittes, Kroniek Vermogensrecht, NJB 2004, p. 1588; A.A. van Rossum, Civielrechtelijke aansprakelijkheid voor overheidstoezicht, in: Toezicht (Handelingen Nederlandse Juristen Vereniging 2005-I), Deventer: Kluwer 2005, p. 95; B.T.M. van der Wiel, De aansprakelijkheid van toezichthouders, MvV 2005, afl. 7, p. 159; I. Giesen, Aansprakelijkheid en toezicht, Deventer: Kluwer 2005, p. 37 e.v.; T. Hartlief in zijn annotatie bij HR 9 juli 2010, ECLI:NL:HR:2010:BL3262, NJ 2015/343 (XL Insurance Company Ltd/Staat), ov. 11; T. Hartlief, Van schurken en toezichthouders, NJB 2010/490, p. 603; R. Rijnhout e.a., Beweging in het aansprakelijkheidsrecht, NTBR 2013/20, in het bijzonder par. 3.4; I. Giesen, Aansprakelijkheid voor inadequate publieke beveiliging door private actoren, in: I. Giesen, J.M. Emaus \& L.F.H. Enneking (red.), Verantwoordelijkheid, ansprakelijkheid en privatisering van publieke taken, Den Haag: Boom Juridische uitgevers 2014, p. 84-85; J. Kortmann, Korte reactie op 'Aansprakelijkheid voor inadequate publieke beveiliging door private actoren', in: I. Giesen, J.M. Emaus \& L.F.H. Enneking (red.), Verantwoordelijkheid, ansprakelijkheid en privatisering van publieke taken, Den Haag: Boom Juridische uitgevers 2014, p. 119. Zie ook eerder over dit onderscheid K.L. Maes, De reikwijdte van de primaire en secundaire zorgplicht: gelijke monniken, gelijke kappen?, AV\&S 2016, afl. 2, p. 4; Maes 2017a, p. 122. de trekker over, en welke partij heeft de schutter daartoe in de gelegenheid gesteld? ${ }^{7}$

Eisers baseren hun vorderingen in de procedure in eerste aanleg - welke vorderingen in hoger beroep worden gehandhaafd, daarover in paragraaf 4.1 meer - op artikel 6:162 van het Burgerlijk Wetboek (hierna: BW) en de artikelen 2, 3 en 8 van het Europees Verdrag tot bescherming van de rechten van de mens en de fundamentele vrijheden (hierna: EVRM). ${ }^{8}$ Het daaraan ten grondslag liggende verwijt van de eisers komt erop neer dat de politie Tristan ten onrechte het wapenverlof heeft verleend, zonder in de beoordeling de weigering van het wapenverlof in 2005 en de gedwongen opname van Tristan in het psychiatrische ziekenhuis in 2006 (en de in dat verband opgemaakte BOPZ-mutatie) te betrekken. Bovendien stellen de eisers dat de politie de WWM ten onrechte restrictief heeft toegepast door Tristan, ondanks de hiervoor geschetste feiten en omstandigheden, een wapenverlof te vergunnen. Eisers menen dat het voornoemde handelen zich als onrechtmatig laat kwalificeren, doordat een en ander zowel handelen in strijd met de wet (WWM) oplevert als handelen in strijd met hetgeen volgens het ongeschreven recht in het maatschappelijk verkeer betaamt.

De politie heeft van meet af aan bestreden dat zij onrechtmatig heeft gehandeld. Bovendien heeft zij aangevoerd dat het causaal verband tussen het onrechtmatig handelen en de schade ontbreekt, omdat Tristan zonder het wapenverlof ook wel op enige wijze - illegaal - aan vuurwapens zou zijn gekomen. Tot slot heeft de politie gemotiveerd betwist dat aan het relativiteitsbeginsel is voldaan.?

\subsection{De uitspraak in eerste aanleg}

De rechtbank stelt voorop dat het feit dat de weigering van het verlof in 2005 en de BOPZ-mutatie door de politie bij de besluitvorming over de vergunningverlening in 2008 buiten

7. Het doel van dit feitelijke onderscheid is een categorisatie aan te kunnen brengen (bijv. bij de vereiste mate van voorzienbaarheid die bij de aansprakelijkheidstoets van primaire, respectievelijk secundaire partijen wordt aangelegd, zoals in par. 5.1.2 van deze bijdrage wordt besproken). Deze secundaire zorgdragers worden in het Amerikaanse recht ook wel als 'peripheral tortfeasors' aangeduid; hun (zorg)rol wordt aldus in het Amerikaanse recht benoemd en erkend, naast de rol van de primaire aansprakelijke partij, de 'immediate tortfeaser'. Zie hierover Van Boom 1997, p. 139; Giesen 2005, p. 37; Giesen 2014, p. 82. Zie over secundaire aansprakelijkheidsvragen in Amerikaans perspectief - in hoeverre moeten toezichthoudende, private partijen worden afgerekend op de gevolgen die zij met adequate security waarschijnlijk hadden kunnen voorkomen? - de bijdrage van O.A. Haazen, Amerikaanse toestanden, NJB 2005/22, p. 1135-1137. Zie eerder over secundaire aansprakelijkheden in het Amerikaanse recht Maes 2017a, p. 122-124.

8. De aangehaalde bepalingen uit het EVRM worden door de rechtbank in enkele overwegingen kort besproken (r.o. 5.50-5.53) en door het hof, bij gebrek aan belang, geheel niet besproken. Om die reden zal ik op deze grondslagen in dit artikel niet nader ingaan. Voor achtergrondinformatie verwijs ik kortheidshalve naar J.M. Emaus, Handhaving van EVRM-rechten via het aansprakelijkheidsrecht (diss. Utrecht), Den Haag: Boom Juridische uitgevers 2013, p. 125-150.

9. Zo blijkt uit r.o. 5.36. Uit de uitspraak blijkt niet welke argumenten daartoe precies zijn aangevoerd. 
beschouwing zijn gelaten, kwalificeert als een handelen in strijd met een wettelijke plicht (de WWM) en daarmee als een onrechtmatige daad van de politie. Indien die gegevens wél waren meegewogen, zou dat naar het oordeel van de rechtbank tot weigering van het wapenverlof hebben moeten leiden; van causaal verband is dus tevens sprake. Ondanks dat de rechtbank de overtreding van de WWM door de politie op deze gronden erkent, wijst zij de vordering van de eisers alsnog af op grond van een beroep op het relativiteitsvereiste in de zin van artikel 6:163 BW.

Daaraan vooraf gaat een analyse van het doel en de strekking van de WWM en de Circulaire Wapens en Munitie 2005 (hierna: CWM). ${ }^{10}$ Zo wordt in r.o. 5.41 overwogen dat uit de memorie van toelichting valt af te leiden dat de WWM ziet op 'de bescherming van de veiligheid van burger en staat', alsmede dat illegaal wapenbezit voorkomen moet worden, vanwege de 'ernstige bedreiging voor het leven en de vrijheid van personen'. ${ }^{11}$ Desondanks oordeelt de rechtbank dat de WWM niet strekt ter bescherming van de (vermogens)schade die eisers hebben geleden doordat Tristan wapens - waarvoor dus ten onrechte verlof was verleend - heeft gebruikt bij het schietincident. Daarbij wijst de rechtbank erop dat onzorgvuldige besluitvorming een onbepaalde en in beginsel onbegrensde groep potentiële gelaedeerden rakt, die op niet in algemene zin te voorziene wijze tot velerlei vormen van schade zou kunnen leiden.

Het beroep van de eisers op de ongeschreven zorgvuldigheidsnorm van artikel 6:162 BW wordt door de rechtbank eveneens afgewezen. Ter onderbouwing daarvan wijst de rechtbank erop dat de zorgvuldigheidsnorm een (klaarblijkelijk: sterk) relatieve norm betreft - 'het is dus niet zo dat elk onzorgvuldig handelen een onrechtmatige daad oplevert jegens eenieder die van dat handelen de gevolgen ondervindt' - en dat de politie bij de verlening van het wapenverlof aan Tristan niet over geobjectiveerde informatie beschikte die wees op een veiligheidsrisico voor willekeurige derden.

\section{De uitspraak van het Gerechtshof Den Haag}

\subsection{De grieven in hoger beroep}

De grieven van eisers (hierna in hoger beroep: appellanten) worden in het arrest van het hof zeer beknopt besproken. Van belang voor de onderhavige bespreking is dat appellanten hebben gegriefd tegen het oordeel van de rechtbank dat niet aan het relativiteitsvereiste zou zijn voldaan, alsmede tegen het oordeel dat er geen ongeschreven betamelijkheidsnorm zou zijn geschonden. ${ }^{12}$

10. Ik verwijs naar r.o. 5.8-5.18 en 5.36-5.42 voor de uitvoerige analyse van de rechtbank.

11. Verwezen wordt naar Kamerstukken II 1976/77, 14413, 1-3, p. 20 en Kamerstukken II 1979/80, 14413, 5, p. 2.

12. De grieven tegen het oordeel omtrent art. 2, 3 en 8 EVRM, de grief omtrent de onvolledigheid van r.o. 2.15 van het vonnis en de grief over de proceskosten laat ik in het onderhavige artikel onbesproken.

\subsection{Het arrest in hoger beroep}

Het Gerechtshof Den Haag legt zijn vinger op de zere plek door in r.o. 7.1 (aan het begin van de beoordeling) direct te overwegen dat wat het hof betreft wél aan het relativiteitsvereiste is voldaan. Na deze aankondiging zoomt het hof weer uit, en volgt er een uiteenzetting over respectievelijk de onrechtmatigheid, de relativiteit en de causaliteit.

\subsubsection{De onrechtmatigheid}

In de eerste plaats de onrechtmatigheid. Het hof stelt in r.o. 7.5 voorop dat voor het antwoord op de vraag of de politie onrechtmatig heeft gehandeld bij het verlenen van het verlof aan Tristan, moet worden nagegaan:

1. welke gegevens de korpschef moet (laten) raadplegen voordat hij op een aanvraag beslist;

2. over welke gegevens betreffende Tristan hij beschikte ten tijde van de beslissing op de aanvraag van oktober 2008 (en/of de latere verlengingen van het verlof); en

3. of die informatie uit die gegevens bedoelde geringe twij$\mathrm{fel}^{13}$ had moeten wekken de wapenvergunning aan Tristan te verstrekken.

Het hof herhaalt in het kader van de beantwoording van deze vragen diverse feiten en omstandigheden zoals genoemd in de uitspraak van de rechtbank. Nadat het hof concludeert dat op het moment van aanvraag in de digitale politieregisters de BOPZ-mutatie was opgenomen, wordt geoordeeld dat deze mutatie ten onrechte niet in de beoordeling van de verlofaanvraag is betrokken (r.o. 7.7-7.8). De politie wist, althans had daarom behoren te weten, dat er sprake was van feiten die tot weigering van het wapenverlof hadden moeten leiden. Of, in de woorden van het hof, op basis van de bij de politie beschikbare gegevens had 'een redelijk handelend en redelijk bekwaam korpschef daarom het verlof moeten weigeren (r.o. 7.14). Daarmee is de normschending ook in hoger beroep een feit.

\subsubsection{De relativiteit}

Vervolgens komt de cruciale vraag naar de relativiteit aan bod. Nadat het hof in r.o. 8.2 alvast voorsorteert op het later door hem te maken onderscheid in de voor vergoeding in aanmerking komende schades, sluit hij in r.o. 8.3 naadloos aan bij de hierna in paragraaf 5.1.1 te schetsen kritieken uit de hoek van Franssen en Van Tilborg over de (te algemene) formulering van de normschending. Overwogen wordt:

'Voor wat betreft de geschonden norm is het hof echter, anders dan de rechtbank, van oordeel dat niet alleen de

13. Dit criterium is te herleiden tot r.o. 1.5 van het arrest, waarin wordt verwezen naar de beschikking uit 2015 (afwijzing wapenverlof van Tristan), en waarin staat opgenomen dat 'uit vaste jurisprudentie blijkt, dat reeds het bestaan van geringe twijfel aan het verantwoord zijn van de te maken uitzondering voldoende reden is om een verlof te weigeren'. In r.o. 7.4 wordt door het hof op dit toetsingskader teruggegrepen door voorop te stellen: 'reeds geringe twijfel aan het verantwoord zijn van het maken van de uitzondering op het wapenverbod is voldoende om de aanvraag te weigeren'. 
norm van een zorgvuldige besluitvorming is geschonden (zie hiervoor onder randnummer 7.21). De schending van die zorgvuldigheidsnorm heeft er in dit geval immers toe geleid dat in strijd met art. 7, lid 1, aanhef en onder b en c van de WWM wapenverlof is verleend. In dat artikel is als norm neergelegd, dat een wapenverlof moet worden geweigerd (niet mag worden verlengd), indien er reden is om te vrezen dat aan de aanvrager het voorhanden hebben van een vuurwapen niet kan worden toevertrouwd of wanneer er vrees is voor misbruik van het wapen, welke reden er al is bij geringe twijfel. Ook die - materiële - norm is geschonden.' (curs. KLM)

De opmars naar een positief relativiteitsoordeel is daarmee ingezet. Met een verwijzing naar de wetsgeschiedenis van de WWM merkt het hof (ter aanvulling op de eerdere analyse van de rechtbank) in r.o. 8.7 op dat 'wapengebruik de rechtsorde in hoge mate aantast. Moord en doodslag, berovingen, gijzelingen en ontvoeringen plegen met behulp van wapens te worden gepleegd. '14 Ook grijpt het hof - zoals ook door Van Tilborg en Franssen betoogd ${ }^{15}$ - terug naar de voorganger van de WWM, te weten de Vuurwapenwet $1919,{ }^{16}$ en de daarin neergelegde doelen. Deze wet maakt glashelder dat met het verlofstelsel voorkomen moest worden dat 'personen met wapenen rondlopen, aan wie zij niet zijn toevertrouwd'. De bedoelde machtiging kon dan ook alleen worden verleend indien een redelijk belang dat vorderde en misbruik van de machtiging of het wapen niet viel te vrezen. 'Hier komt de persoonlijkheid van den aanvrager in het geding, waaromtrent de politie zich zal hebben te vergewissen', aldus het hof, citerend uit de voornoemde Vuurwapenwet in r.o. 8.9-8.10.

De (nadere) analyse van de Vuurwapenwet 1919, mede bezien in het licht van hetgeen in de wetsgeschiedenis van de WWM is opgenomen, brengt het hof tot het (de) verlossende woord(en) in r.o. 8.12:

'Met het opnemen van de weigeringsgronden beoogde de wetgever dus te voorkomen dat bepaalde personen (misdadigers, zieken van geest en kinderen) een vuurwapen in handen zouden krijgen en daarvan misbruik zouden maken, waardoor de veiligheid van de burger in gevaar zou komen en er slachtoffers zouden vallen. Het voorkomen van dat gevaar voor anderen als gevolg van misbruik is een uitdrukkelijk door het hoofd van politie/de korpschef te beoordelen risico dat in voorkomend geval tot weigering van een gevraagd verlof moet leiden. Vuurwapens behoren

14. Kamerstukken II 1984/85, 14413, 9, p. 2 (NV).

15. T.W. Franssen \& D. van Tilborg, De ingewikkelde zoektocht naar doel en strekking van de geschonden norm, O\&A 2015/30, p. 61-62.

16. In de MvT op de WWM wordt die regeling van het legale bezit van vuurwapens in de Vuurwapenwet 1919 'vrijwel perfect' genoemd (Kamerstukken II $1976 / 77,14413,1-3$, p. 20). Aangenomen moet dan ook worden dat de wetgever beoogd heeft in zoverre de regeling van het legale bezit van wapens uit de Vuurwapenwet 1919 inhoudelijk ongewijzigd voort te zetten. Zie hierover (nader) r.o. 8.11 van het arrest. niet in handen te komen van personen aan wie die wapens niet kunnen worden toevertrouwd.

Het hof neemt dan ook aan dat de geschonden norm - de norm dat een wapenverlof geweigerd moet worden aan iemand aan wie een vuurwapen niet kan worden toevertrouwd, omdat vrees voor misbruik bestaat - ook (specifiek) tot doel heeft om de burger in zijn individuele belang te beschermen tegen de schadelijke gevolgen van het gebruik (misbruik) van een vuurwapen.' (curs. KLM)

Daarmee is in hoger beroep, in tegenstelling tot het oordeel van de rechtbank en ten gunste van appellanten, de relativiteitsdrempel van artikel 6:163 BW genomen.

\subsubsection{De causaliteit}

Dan, tot slot, de causaliteit. Dit oordeel valt te onderscheiden in (a) het conditio sine qua non-verband en (b) de redelijke toerekening van artikel 6:98 BW.

Het hof maakt - in navolging van de rechtbank - korte metten met het op (a) betrokken verweer van de politie dat het causaal verband tussen het onrechtmatig handelen en de schade zou ontbreken, omdat Tristan zonder het wapenverlof ook wel op enige wijze, illegaal, aan vuurwapens zou zijn gekomen (r.o. 9.1). Indien de politie onrechtmatig heeft gehandeld door ten onrechte een wapenverlof af te geven en Tristan als gevolg daarvan met zijn vuurwapens op mensen heeft geschoten die daardoor schade hebben geleden, wordt het oorzakelijk verband tussen dat onrechtmatig handelen en die schade niet verbroken doordat zich andere feiten hadden kunnen voordoen die eveneens tot een zodanige schade zouden hebben geleid, aldus het hof kernachtig.

Het verweer van de politie met betrekking tot (b), de redelijke toerekening van artikel 6:98 BW, slaagt (deels) wel. De politie had zich er in hoger beroep immers ook op beroepen dat de schade haar in redelijkheid niet kon worden toegerekend als bedoeld in artikel 6:98 BW, met name omdat:

1. zij hooguit kon weten dat Tristan kortdurend was opgenomen omdat hij suïcidaal was en zij dus niet kon voorzien dat Tristan gevaarlijk zou kunnen zijn voor anderen en al helemaal niet dat hij in staat zou zijn tot hetgeen hij op 9 april 2011 heeft aangericht;

2. de schade niet rechtstreeks is veroorzaakt door het verlenen van het verlof, maar dat zich daartussen nog allerlei tussenschakels bevinden (vooral beslissingen en handelingen van Tristan), waardoor er sprake is van een te ver verwijderd verband;

3. de fout van de politie niet een ernstige fout betreft, maar slechts uit onzorgvuldigheid bestaat; het gaat niet om een ernstige nalatigheid, maar om het niet meenemen van bepaalde informatie. 
Met een (impliciete) verwijzing naar de deelregels van Brunner in r.o. $9.4^{17}$ overweegt het hof dat de (door hem geherformuleerde) geschonden norm - de norm dat een wapenverlof geweigerd moet worden aan iemand aan wie een vuurwapen niet kan worden toevertrouwd, omdat vrees voor misbruik bestaat - strekt tot bescherming van de burger in zijn individuele belang tegen de schadelijke gevolgen van het gebruik (misbruik) van een vuurwapen. De aard van deze norm brengt volgens het hof mee dat aan de voorzienbaarheid van de schade minder hoge eisen hoeven te worden gesteld. Met deze voorzienbaarheidsmaatstaf in de hand en met een verwijzing naar buitenlandse incidenten van suïcide met voorafgaande homicide met behulp van (legale) vuurwapens, oordeelt het hof dat 'niet kan worden gezegd dat voor de politie ten tijde van de verlening van het verlof onvoorzienbaar was dat Tristan vuurwapen(s) tegen anderen zou gaan gebruiken'. Integendeel, dat was toen in zekere zin wel te voorzien, aldus het hof in r.o. 9.6.

Zoals de oplettende lezer in de inleidende r.o. 8.2 al tussen de regels door gelezen had, maakt het hof vervolgens een 'knip' in de voor vergoeding in aanmerking komende schade. Overwogen wordt in r.o. 9.7:

'Deze zekere mate van voorzienbaarheid, waarbij ook nog geldt dat voor de hand ligt dat, wanneer tegen anderen misbruik wordt gemaakt van een vuurwapen, dit kan leiden tot letsel en dat er (een) gewonde(n) zo niet dode(n) $\operatorname{val}(\mathrm{t})$ len, en de strekking van de geschonden norm brengen mee dat aan PHM (alleen) dié schade kan worden toegerekend waarbij een ruime toerekening past, dus alleen materiële en immateriële letsel- en overlijdensschade. Die schade staat niet in zodanig verwijderd verband van de normschending dat op grond daarvan toerekening achterwege moet blijven.' (curs. KLM)

Het hof komt in r.o. 9.8 tot de slotsom dat de politie aansprakelijk is voor de schade zoals die door appellanten is geleden, maar slechts voor zover het schade als gevolg van lichamelijk letsel of overlijden betreft. Dat appellanten tot een onbepaalde groep behoorden, is daarbij niet van belang. Andere schadeposten dan letsel- en overlijdensschade (zaakschade en zuivere vermogensschade) kunnen echter niet aan de politie worden toegerekend; ten aanzien van deze schadeposten treft het artikel 6:98 BW-verweer van de politie in hoger beroep dus doel.

In de navolgende paragrafen neem ik de componenten van de relativiteit (par. 5) en de voor vergoeding in aanmerking komende schade (par. 6) nader onder de loep, een en ander bezien in het licht van de kritieken waarmee het vonnis in eerste aanleg is ontvangen. Ten aanzien van de overige componenten van de aansprakelijkheid - zoals bijvoorbeeld de normschending - volsta ik met hetgeen ik daarover reeds heb opge-

17. C.J.H. Brunner, Causaliteit en toerekening van schade, VR 1981, p. 21 e.v. en p. 233 e.v. en Asser/Hartkamp \& Sieburgh 6-II 2017/63. merkt, daar waar het hof over die componenten geen principieel ander standpunt inneemt dan de rechtbank.

\section{De relativiteit}

\subsection{Het vonnis van de rechtbank: waar ging het fout?}

\subsubsection{De schending van de wettelijke norm}

Ik merkte al eerder op dat het vonnis in eerste aanleg in de daarover verschenen literatuur kritisch is ontvangen. ${ }^{18}$ Deze kritiek zag meer in het bijzonder op de afwijzing van de aansprakelijkheid op grond van het relativiteitsvereiste, daar waar de geschonden norm (WWM) niet zou strekken ter bescherming van de door eisers geleden schade.

Zo vroeg ten eerste Giesen zich naar aanleiding van de overwegingen van de rechtbank op dit punt hardop af 'hoe onbegrijpelijk de rechtspraak - en het relativiteitsvereiste - kan zijn'. ${ }^{19}$ Giesen heeft in het bijzonder kritiek op het onderscheid dat de rechtbank in r.o. 5.43 maakt tussen de met de WWM gediende algemene maatschappelijke veiligheidsnorm van bescherming van de veiligheid van de samenleving en de door de politie geschonden norm van de onzorgvuldige besluitvorming bij verlening van een wapenverlof. Alhoewel dit onderscheid valt te herleiden tot het Duwbak Linda-arrest, ${ }^{20}$ merkt hij op dat 'dat toch echt een ander gevaltype betrof. Een onzorgvuldige keuring van een schip is immers niet hetzelfde als een onzorgvuldig besluit inzake een wapenvergunning. ${ }^{21}$ Giesen wijst als verklaring voor de terughoudendheid van de rechtbank op de angst dat het hek met toewijzing van de aansprakelijkheid in dergelijke zaken van de dam is, door op te merken:

'De Rechtbank komt tot haar andere oordeel, zo leid ik af uit het voorgaande, uit angst voor een ongehoord groot aantal claims, van grote groepen claimanten, tegen de overheid die daarvoor dan te snel aansprakelijk kan worden gehouden.' $^{22}$

Ook Di Bella is kritisch, en noemt het een 'kleine stap' van de normschending 'naar het oordeel dat de in deze zaak geleden schade onder het beschermingsbereik van de geschonden norm valt'. Zij wijst daarbij eveneens op de onterecht gemaakte vergelijking tussen de onderhavige zaak en het Duwbak Linda-arrest, daar waar het in de eerste zaak om letselschade gaat, en in de laatste zaak om zaak- en vermogensschade. 'Dit ver-

18. Ik bespreek in het navolgende de bijdragen van Giesen, Di Bella, Meijer en de annotatie van Schutgens kort en verwijs voor de context van hun kritieken naar de hierna genoemde bijdragen. Daar waar het hof opvolging lijkt te geven aan de bijdrage van Franssen en Van Tilborg, zal ik met name hun bijdrage in het vervolg nader onder de loep nemen.

19. I. Giesen, Aansprakelijkheid na de schietpartij in Alphen aan den Rijn hoe onbegrijpelijk kan rechtspraak - en het relativiteitsvereiste - zijn? WPNR 2015/7055.

20. HR 7 mei 2004, NJ 2006/281 (Duwbak Linda).

21. Giesen 2015, p. 277.

22. Giesen 2015, p. 279. 
schil zou op zichzelf al een goede reden kunnen zijn geweest om in Alphen een minder beperkend relativiteitsoordeel te geven', aldus deze auteur. ${ }^{23}$ Ook zij merkt over de verklaring voor deze terughoudendheid op dat het erop lijkt dat 'het relativiteitsvereiste wordt ingezet om een (te) vergaande overheidsaansprakelijkheid te voorkomen'.24

Schutgens verbindt aan het relativiteitsoordeel van de rechtbank in zijn annotatie bij het vonnis de conclusie dat de wet 'kennelijk' weinig tot geen aanspraken voor individuen schept, als we de rechtbank in haar redenering zouden volgen. ${ }^{25}$ Het is immers aan de orde van de dag dat de wetgever bij de totstandkoming van publiekrechtelijke toezichtsregeling en vergunningsstelsels in de eerste plaats een algemeen belang voor ogen heeft. ${ }^{26}$ Schutgens concludeert vervolgens:

'Als de burgerlijke rechter vervolgens bij zijn relativiteitsonderzoek zó nadrukkelijk inzoomt op de parlementaire geschiedenis, dan zal hij bij zulke publiekrechtelijke wetgeving al snel, eigenlijk te snel, concluderen dat de betreffende regeling kennelijk niet tot bescherming van individuen strekt. (...) Het ware dan ook beter als de rechter, in die gevallen waarin de parlementaire geschiedenis niet uitdrukkelijk beantwoordt of een wet individuele aanspraken al dan niet beschermt, hetzij de eiser het voordeel van de twijfel geeft, hetzij een eigen, genuanceerdere, minder "digitale" interpretatie van de strekking van de regeling geeft. $^{27}$

Ook Franssen en Van Tilborg analyseren de uitspraak uitvoerig en trekken, na een - ik zou bijna zeggen - 'ontleding' van het relativiteitsvereiste, in twijfel of 'de motivering die de rechtbank in het vonnis heeft opgenomen haar conclusie kan dragen'. ${ }^{28}$ Als verklaring voor de 'gaten' in de motivering wijzen Franssen en Van Tilborg erop dat door de rechtbank zowel bij de doel- als bij de strekkingsvraag een onjuiste formulering van de geschonden norm is gehanteerd.

Zonder met deze korte samenvatting recht te doen aan de uitvoerige en treffende analyse die daaraan voorafgaat - en waarnaar ik dus kortheidshalve verwijs ${ }^{29}$ - stellen Franssen en Van Tilborg ter onderbouwing van die conclusie dat de rechtbank de norm onjuist (en algemener) formuleert als 'een zorgvuldige besluitvorming bij verlening van het wapenverlof, terwijl de rechtbank eerder had overwogen dat het besluit naar het

23. L. Di Bella, Geen aansprakelijkheid politie voor onterecht verlenen wapenverlof. Een bespreking van de onrechtmatige overheidsdaad aan de hand van Rb. Den Haag 4 februari 2015 (schietpartij Alphen aan den Rijn), AV\&S 2016/23, afl. 3, p. 130.

24. Di Bella 2016, p. 130.

25. R.J.B. Schutgens, annotatie bij Rb. Den Haag 4 februari 2015, ECLI:NL:RBDHA:2015:1061, JIN 2015/213, ov. 5.

26. Zo merkt ook Di Bella op in L. Di Bella, De toepassing van de vereisten van causaliteit, relativiteit en toerekening bij de onrechtmatige overheidsdaad, Deventer: Kluwer 2014.

27. Schutgens 2015 , ov. 5 .

28. Franssen \& Van Tilborg 2015, p. 60 en 66.

29. Franssen \& Van Tilborg 2015, p. 60-66. oordeel van de rechtbank niet alleen onzorgvuldig was voorbereid, maar bovendien materieel gezien onjuist en dus in strijd met het recht was verleend. De daadwerkelijk geschonden materiële norm is volgens de auteurs dan ook dat een wapenverlof moet worden geweigerd (respectievelijk niet mag worden verlengd), indien er reden is om te vrezen dat van de wapens misbruik zal worden gemaakt. ${ }^{30}$ Bedacht dient te worden dat, aldus de auteurs, 'de wijze waarop de geschonden norm wordt geformuleerd, niet slechts een semantische kwestie betreft, maar van doorslaggevende betekenis kan zijn voor het antwoord op de relativiteitsvraag' c.q. 'ertoe kan leiden dat het onderzoek naar het doel en de strekking van de geschonden norm wordt vertroebeld en bemoeilijkt' ${ }^{31}$

Dat de formulering van de geschonden norm consequenties kan hebben voor het relativiteitsoordeel, maken de auteurs vervolgens inzichtelijk door te wijzen op het naar aanleiding van het Duwbak Linda-arrest in r.o. 5.43 gemaakte onderscheid tussen de 'gediende algemene maatschappelijke veiligheidsnorm van de bescherming van de veiligheid van de samenleving' enerzijds en de geschonden norm van een 'onzorgvuldige besluitvorming bij verlening van een wapenverlof anderzijds, waar ook (zo besprak ik hiervoor) Giesen op aansloeg. In dit deel van de motivering van de uitspraak zijn naar de mening van de auteurs de gevolgen te zien van de hiervoor omschreven onjuiste (en te algemene) formulering van de geschonden norm. De rechtbank heeft zich door deze algemeen geformuleerde geschonden norm immers slechts verhouden tot de algemene primaire doelstelling van de WWM, zijnde het reguleren van het bezit van legale wapens en het voorkomen van illegaal wapenbezit. Niet is door de rechtbank ingegaan op hetgeen de wetgever voor ogen stond met het opnemen van de (specifiek in dit geval aan de orde zijnde) weigeringsgronden voor een wapenverlof, te weten dat een wapenverlof moet worden geweigerd (respectievelijk niet mag worden verlengd), indien er reden is om te vrezen dat van de wapens misbruik zal worden gemaakt. Dat had zij volgens de auteurs wel moeten doen, en dus, zo begrijp ik hun betoog, ook gedaan als de norm concreter was geformuleerd, in dier voege dat ook de (materiële) schending van de norm in het relativiteitsoordeel was betrokken. De algemeen geformuleerde norm bracht de rechtbank zodoende tot de onjuiste overweging dat deze norm moet worden onderscheiden van de geschonden zorgvuldigheidsnorm, en dat die laatste norm (slechts) 'bijdraagt' aan de verwezenlijking van de algemene norm, aldus de auteurs. ${ }^{32}$ Dat de auteurs hiermee de spijker op de kop slaan, blijkt wel uit de door het hof gehanteerde en van de rechtbank afwijkende definitie van de normschending - dezelfde definitie als Franssen en Van Tilborg aanlegden -

30. Franssen \& Van Tilborg 2015, p. 61.

31. Franssen \& Van Tilborg 2015, p. 59-60.

32. De specifieke doelstelling, geplaatst tegen de achtergrond van de door de rechtbank genoemde algemene en nevendoelstellingen van de WWM, leidde juist tot de conclusie dat er zeer goede argumenten bestaan om aan te nemen dat de geschonden norm (specifiek) tot doel heeft om te beschermen tegen de schade zoals die door eisers is geleden, aldus Franssen \& Van Tilborg 2015, p. 61. 
en de consequentie voor het positieve relativiteitsoordeel in hoger beroep.

Ook ik was eerder kritisch over de afwijzing van de aansprakelijkheid van de politie op relativiteitsgronden. ${ }^{33}$ Meer in het algemeen vond en vind ik het moeilijk te volgen dat de rechtbank éérst vaststelt dat uit de memorie van toelichting valt af te leiden dat de WWM ziet op de bescherming van de veiligheid van burger en Staat, alsmede op het voorkomen van illegaal wapenbezit, en wel vanwege de ernstige bedreiging voor het leven en de vrijheid van personen - een beter voorbeeld dan het schietincident lijkt niet voorhanden, zou je denken om vervolgens te oordelen dat daarmee niet gezegd is dat deze zelfde wet strekt ter bescherming van de schade die eisers hebben geleden doordat Tristan wapens, waarvoor ten onrechte verlof was verleend, heeft gebruikt bij het schietincident. ${ }^{34}$ Met andere woorden: dat Tristan door de onterecht verleende vergunning van het wapenverlof een groot aantal mensen heeft kunnen neerschieten en vermoorden, valt volgens de rechtbank buiten de strekking van een wet, die volgens de wetsgeschiedenis juist beoogde de burger (en dus ook deze mensen) tegen ernstige bedreigingen van het leven te beschermen. Ter bescherming van welke schade en/of belangen dient deze wet dan wél?

Deze uitspraak past wat mij betreft in een bredere tendens in de rechtspraak waarin een zekere terughoudendheid bestaat om overheidsaansprakelijkheid aan te nemen, en misschien wel met name daar waar de overheid als secundaire partij wordt aangesproken en er dus een primaire (mede)veroorzaker in het spel is. ${ }^{35}$ Zo concludeert ook Meijer, die opmerkt dat het vonnis van de rechtbank 'op zichzelf in lijn is met de meer stringente benadering van relativiteit bij overheidsaansprakelijkheid, zoals deze het laatste decennium lijkt te zijn ingezet'. ${ }^{36}$ Meijer wijst daarbij eveneens op 'het indammen van een te ver uitdijende overheidsaansprakelijkheid' als 'duidelijke achtergrond' van deze strenge toets. ${ }^{37}$ Ook Hartlief merkt in zijn annotatie bij de uitspraak over de vuurwerkramp in Enschede op dat het aansprakelijk stellen van overheden tot dan toe 'weinig heeft mogen baten', daar waar de overheid bij het beoordelen daarvan de 'nodige afstand bewaart' en, aldus Hartlief, 'nogal voorzichtig is'. ${ }^{38}$

33. Maes 2017a, p. 127.

34. Maes 2017a, p. 124-125 en K.L. Maes, De overheid als secundaire ansprakelijke partij in het civiele (letselschade)recht, in: C. de Beer, S.J.F. Heirman, E.C. Huijsmans \& R. van den Munckhof (red.), Overheidsaansprakelijkheid in milieu- en gezondheidszaken, Nijmegen: Wolf Legal Publishers 2017, p. 45-50 (hierna: Maes 2017b).

35. T. Hartlief in zijn annotatie bij HR 9 juli 2010, ECLI:NL:HR: 2010:BL3262, NJ 2015/343 (XL Insurance Company Ltd/Staat). Zie over deze terughoudendheid eerder en uitgebreid Maes 2017b, p. 42-46.

36. R. Meijer, Relativiteitsperikelen: Wet wapens en munitie geen schild tegen concrete (vermogens)schade?, MvV 2015, afl. 3, p. 78.

37. Meijer 2015, p. 79.

38. T. Hartlief in zijn annotatie bij HR 9 juli 2010, ECLI:NL:HR: 2010:BL3262, NJ 2015/343 (XL Insurance Company Ltd/Staat), ov. 6.
Diverse auteurs - onder wie ikzelf - hebben zich over deze principiële terughoudendheid van de rechter ten opzichte van secundaire (overheids)aansprakelijkheid op zowel morele als juridisch-dogmatische gronden kritisch uitgelaten. Voor wat betreft de genoemde 'het hek van de dam'- en 'de geest uit de fles'-argumenten merken Franssen en Van Tilborg (en met het oog op deze specifieke Alphen aan den Rijn-zaak) op:

'Dat wil niet zeggen dat die terughoudendheid ook in dit geval reeds daarom tot het oordeel zou moeten leiden dat niet aan het relativiteitsvereiste is voldaan. Dat vergt een concrete afweging, die heel wel tot de conclusie kan leiden dat wél aan het relativiteitsvereiste is voldaan en waardoor de gewenste terughoudendheid (in verband met de gevolgen van de - hoogte van - de claims waarmee de overheid geconfronteerd kan worden) dient te wijken.'

Overtuigend wijzen Franssen en Van Tilborg in dit verband op het rapport dat de Onderzoeksraad voor Veiligheid heeft uitgebracht over het schietincident in Alphen aan den Rijn, waaruit volgt dat er in de jaren 1999-2011 in totaal 21 doden zijn gevallen door het gebruik van legale vuurwapens (inclusief degenen die zijn overleden als gevolg van het schietincident). De Onderzoeksraad voor de Veiligheid kwalificeert het aantal incidenten met legale vuurwapens dan ook als betrekkelijk klein. ${ }^{39}$ Giesen werpt bovendien de meer morele vraag op of het niet 'de overheid zelf is die het in haar macht heeft om die stortvloed aan claims (als de vrees daarvoor feitelijk al gerechtvaardigd is) te voorkomen door de vergunningverlening nauwkeurig en adequaat, op grond van alle beschikbare en relevante informatie, aan te pakken, en zo incidenten als in Alphen aan den Rijn te voorkomen, althans minder te "faciliteren"'? 40 Ook Kortmann en Hartlief wezen eerder op deze verantwoordelijkheid van secundaire partijen, om daarmee een terughoudende aansprakelijkheidstoetsing van deze partijen te ontzenuwen. ${ }^{41}$ Ik betoogde, tot slot, eerder dat een principiële terughoudendheid in dit soort secundaire (overheids)aansprakelijkheidsprocedures in het licht van het wettelijke systeem van het aansprakelijkheidsrecht niet goed te rechtvaardigen is. Ter onderbouwing wees ik erop, kort gezegd, dat daarmee de keuzevrijheid van het slachtoffer - en daarmee het systeem van de hoofdelijke aansprakelijkheid - ten onrechte wordt omzeild. ${ }^{42}$

Spier lijkt in dit soort secundaire overheidsaansprakelijkheidszaken terughoudendheid ten aanzien van het relativiteitsvereiste (wel) te bepleiten. Hij merkt hierover op dat in gevallen als de onderhavige niet licht geconcludeerd mag worden dat aan het relativiteitsvereiste is voldaan. Hij vreest dat anders 'de geest uit de fles' zou zijn, aangezien dit tot niet-onaanzienlijke

39. Franssen \& Van Tilborg 2015, p. 64-65.

40. Giesen 2015, p. 279.

41. Hartlief 2010, p. 603; Kortmann 2014, p. 117-123.

42. Voor nadere toelichting op dit standpunt verwijs ik graag naar Maes 2016, p. 7; 2017b, p. 50. 
claims aan het adres van de overheid aanleiding zou kunnen geven. ${ }^{43}$

Ondanks de kritische noot over het grote belang dat de rechtbank aan de tekst van de parlementaire geschiedenis toekent in haar relativiteitsonderzoek, noemt ook annotator Schutgens het relativiteitsoordeel van de rechtbank 'overtuigend'. ${ }^{4}$ Bijval voor (de terughoudendheid van) de rechtbank komt bovendien uit de hoek van Den Hollander. Den Hollander is van mening dat het oordeel van de rechtbank valt te rechtvaardigen vanuit een institutioneel perspectief, waarin de verhouding tussen de rechter en de wetgever centraal staat. Dit perspectief brengt mee dat, indien de wetgever geen duidelijkheid verschaft over de vraag of de geschonden norm individuele vermogensbelangen beoogt te beschermen (zoals in de onderhavige zaak naar de mening van Den Hollander kennelijk het geval is), een terughoudende opstelling van de rechter geboden is. ${ }^{45}$

43. A-G Spier in zijn conclusie bij HR 7 mei 2004, ECLI:NL:HR: 2004:A06012.

44. Schutgens 2015 , ov. 1 en 5 . Zie ook zijn annotatie bij het arrest van het hof: R.J.B. Schutgens \& E.G.A. van der Werf, Gerechtshof Den Haag, 27-03-2018, ECLI:NL:GHDHA:2018:541, 200.171.422/01 (annotatie), JB 2018/102.

45. In zijn proefschrift stelt Den Hollander een model voor aan de hand waarvan niet alleen de relativiteit in een concreet geval kan worden vastgesteld, maar ook de rechtspraak over relativiteit kan worden besproken. In dit model wordt onderscheid gemaakt tussen het materieel aansprakelijkheidsrechtelijk perspectief, waarbij het gaat om de wenselijkheid van de uitkomst die de rechter bereikt, en het institutionele perspectief van de legitimiteit van het relativiteitsoordeel. Hierbij gaat het om de legitimiteit van het relativiteitsoordeel in het licht van de verhouding tussen rechter en wetgever. Dit institutionele perspectief stelt Den Hollander voorop. Vervolgens moet onderscheid worden gemaakt tussen de abstracte vraag naar het 'beschermingsdoel' (of de betreffende norm naast algemene belangen ook individuele vermogensbelangen beoogt te beschermen) en de eventueel daarop volgende concrete vraag naar de 'beschermingsomvang' (of het geschade belang van de benadeelde onder die individuele vermogensbelangen kan worden geschaard). Den Hollander betoogt vervolgens dat er vanuit het institutionele perspectief goede reden is voor de rechter bij de vraag naar het beschermingsdoel een terughoudende opstelling te kiezen in zijn verhouding tot de wetgever en de beantwoording van deze vraag aan de wetgever over te laten. Met andere woorden: de rechter neemt alleen aan dat de norm naast algemene belangen ook individuele vermogensbelangen beoogt te beschermen indien er positieve aanwijzingen zijn in de wettekst en wetsgeschiedenis van de geschonden norm. Vanuit dit perspectief zijn de ontkennende relativiteitsoordelen dus te rechtvaardigen, aldus Den Hollander. Bij de vraag naar de beschermingsomvang mag de rechter wel voor een 'actievere' opstelling kiezen en beantwoording van deze vraag zelf ter hand nemen. Hier kan de rechter dus eigen, al dan niet 'rechtspolitieke' keuzes maken op basis van materieel aansprakelijkheidsrechtelijke overwegingen. P.W. den Hollander, De relativiteit van wettelijke normen (diss. Leiden), Den Haag: Boom juridisch 2016, p. 18-19 en 327 en ook R. Meijer, De relativiteit van wettelijke normen en de toepassing van de vereisten van causaliteit, relativiteit en toerekening bij de onrechtmatige overheidsdaad. Bespreking van de proefschriften van mr. P.W. den Hollander en mr. L. Di Bella, MvV 2017, afl. 1, p. 8. Zie nader P.W. den Hollander, Fout, maar niet aansprakelijk. Overheidsaansprakelijkheid en relativiteit in dubbel perspectief naar aanleiding van de Alphense schietpartij, in: R.J.N. Schlössels e.a. (red.), De burgerlijke rechter in het publiekrecht, Deventer: Wolters Kluwer 2015, p. 101-126.

\subsubsection{De ongeschreven zorgvuldigheidsnorm}

Inzoomend op het wezen van de hier centraal staande aansprakelijkheid - een secundaire - kunnen bovendien vraagtekens worden geplaatst bij de afwijzing van de aansprakelijkheid op grond van de ongeschreven zorgvuldigheidsnorm van artikel 6:162 BW. Ter onderbouwing daarvan wees de rechtbank er in het bijzonder op dat de zorgvuldigheidsnorm een relatieve norm betreft en slechts tot zorgvuldigheid verplicht die in een bepaalde verhouding tegenover één of meer anderen moet worden betracht. Daarvoor moet vast komen te staan, aldus de rechtbank, dat de politie voor haar kenbare belangen van derden heeft veronachtzaamd. $\mathrm{Nu}$ de politie bij de verlening van het wapenverlof aan Tristan niet over geobjectiveerde informatie beschikte die wees op een veiligheidsrisico voor willekeurige derden bij verlening van een wapenverlof aan Tristan, oordeelde de rechtbank dat de politie geen ongeschreven zorgvuldigheidsnorm jegens de eisers heeft geschonden. Ook hier betrof de relativiteit, in feite ingevuld door de voorzienbaarheid, de spreekwoordelijke stok om mee te slaan. Deze 'voorzienbaarheidsvraag' betrok de rechtbank ook in haar relativiteitsoordeel over de vraag of de wettelijke norm (WWM) strekte ter bescherming van de schade zoals door de eisers geleden, zo besprak ik in paragraaf 3.2, zodat het hierna opgemerkte gedeeltelijk ook op die overwegingen slaat.

De vraag is ten eerste of de conclusie die de rechtbank over de voorzienbaarheid trekt, terecht is. Daar waar de rechtbank eerder vaststelde dat de politie het wapenverlof niet had behoren te verlenen aangezien zij had moeten vrezen voor misbruik met het wapen, en daarmee de normschending vaststelde (r.o. 5.10, 5.13 en 5.23), is de voorzienbaarheid van dat uiteindelijk gerealiseerde misbruik toch een gegeven? Wellicht was niet voorzienbaar dat er een schietincident van deze omvang plaats zou vinden - wanneer wel? - maar op zijn minst was wat mij betreft voorzienbaar dat het vergunnen van een wapenverlof aan een geesteszieke en instabiele jongen als Tristan met een zekere mate van waarschijnlijkheid tot 'misbruik' zou leiden. Is dat niet voorzienbaar genoeg?

De hiervoor aangehaalde auteurs Franssen, Van Tilborg en Giesen menen ook dat misbruik van het wapen in dit geval een voor de politie algemeen voorzienbaar gevolg is, ondanks dat niet op voorhand duidelijk is op welke manier precies misbruik van het wapen zal worden gemaakt. Giesen merkt in dit verband - refererend aan r.o. 5.44 - treffend op:

'Vuurwapens zijn om te schieten, toch? Oké, je kunt er ook iemand mee slaan, maar dat is zeker niet het primair beoogde gebruik. ${ }^{46}$

Ook Meijer merkt op dat hij toch 'zou menen dat als er een indicatie bestaat dat iemand zelfmoordneigingen heeft, wat moet leiden tot weigering van een wapenvergunning, er toch ook redelijkerwijs geobjectiveerde twijfel kan bestaan of deze

46. Franssen \& Van Tilborg 2015, p. 64 en Giesen 2015, p. 278. 
persoon wel de beschikking moet hebben over een wapen in verband met de risico's voor derden, ook als dit gevaar voor derden (nog) niet expliciet is vastgesteld'. ${ }^{47}$

Nog los van de vraag of het concrete schadeveroorzakende handelen van Tristan voor de politie voorzienbaar (genoeg) was, kan ten tweede de meer abstracte vraag worden gesteld of de rechtbank voor de aansprakelijkheid van de politie terecht een specifiek en concreet kenbaar gevaar vereist. Zijn in de hiervoor aangehaalde strikte redenering van de rechtbank - waarin een dermate specifiek en concreet kenbaar gevaar wordt geëist dat de politie zo ongeveer had moeten bevroeden dat Tristan op een dag het vuur op bezoekers van dat winkelcentrum zou openen - incidenten als de onderhavige niet altíjd in een bepaalde mate onvoorzienbaar, zodat (deze redenering volgend) dan in feite nooit secundaire aansprakelijkheid kan volgen, hoe grof de normschending ook is?

Het stellen van onrealistische voorzienbaarheidseisen is met name problematisch bij de aansprakelijkheid van secundaire partijen, zo betoogde ik al eerder. ${ }^{48} \mathrm{Ik}$ licht dat kort toe.

Een (secundaire) zorgplicht kan slechts dan bestaan als er een bepaalde zorgrelatie tussen de 'zorgdrager' en de 'zorgontvanger' bestaat die bepaalde zorgdaden met zich brengt. ${ }^{49} \mathrm{Bij}$ de aansprakelijkstelling van secundaire partijen gaat het echter in de regel om vrij algemene zorgdaden en verantwoordelijkheden die ten grondslag liggen aan de vaak niet zeer concrete zorgrelatie. Denk hierbij aan de zorg om de veiligheid te waarborgen, het organiseren van toezicht om onbekende ongevallen c.q. aanslagen te voorkomen en de verantwoordelijkheid tot het lokaliseren van afdoende politie en beveiliging om tijdig te kunnen ingrijpen. De hierin gelegen mate van abstractie komt met name naar voren als deze secundaire zorgdaden worden vergeleken met de primaire zorgdaden van een ziekenhuis tegenover zijn patiënt (bijvoorbeeld genezing van ziekte A) of een bank tegenover zijn klant (bijvoorbeeld sparen met maximaal rendement). Het verschil is dat bij de primaire zorgplicht (1) de groep zorgontvangers duidelijk afgebakend en te concretiseren valt en (2) de behoefte van de zorgontvangers, en dus hetgeen waar de zorgrelatie zich op richt (genezing, winstmaximalisatie), vooraf duidelijk is, terwijl het bij de secundaire zorgplicht eerder om speculatieve en vooraf ongekende gevaren gaat. De consequentie is dat het bij deze secundaire zorgplichten haast per definitie lastiger is aan te geven om wat voor zorgrelaties het precies gaat - laat staan dat deze vooraf en in concrete termen te vangen zijn -, met als resultaat weinig tot geen allesomvattende zorgdefinities. ${ }^{50}$ Het zal dan dus ook, juist in dit soort secundaire aansprakelijkheidsgevallen, in veel gevallen onmogelijk zijn bij voorbaat (alle) door de norm beschermde belangen te formuleren, laat staat achteraf te con-

47. Meijer 2015, p. 79.

48. Maes 2016, p. 6-8 en Maes 2017a, p. 127-128.

49. Ik baseer mij op het werk van T.F.E. Tjong Tjin Tai, Zorgplichten en zorgethiek (diss. Amsterdam UvA), Deventer: Kluwer 2006, p. 69-71.

50. Deze alinea is ontleend aan Maes 2016, p. 7. strueren dat de gevolgen precies in die vorm en mate voor de secundaire partij voorzienbaar waren. ${ }^{51}$

Toegepast in de onderhavige casus betekent het voorgaande dat gebrek aan kennis aan de zijde van de politie van het specifieke schadeveroorzakende handelen van Tristan - en daarmee een bepaalde mate van onvoorzienbaarheid van dit schadeveroorzakende gedrag én de schade - wat mij betreft inherent is te noemen aan het 'wezen' van secundaire aansprakelijkheid. De vereiste zorgdaden van de politie worden per definitie afgeleid van wat veronderstellenderwijs met het oog op de algemene veiligheid van een vooraf onbepaalbare en abstracte groep zorgontvangers (in casu: de eisers) gewenst handelen is. ${ }^{52}$ Dat de zorgplicht van de politie strekte ter bescherming van in bepaalde mate speculatieve en vooraf ongekende gevaren, is, met andere woorden, verklaarbaar door haar secundaire 'aard', waarbij de precieze zorgontvanger én diens zorgbehoefte dus niet vooraf kenbaar zijn.

Door nu aan de mate van (on)voorzienbaarheid, zoals deze is verbonden aan de betreffende secundaire zorgplicht van de politie, aansprakelijkheidsbeperkende conclusies te verbinden, geeft de rechtbank (waarschijnlijk onbedoeld) eerder een meer principieel oordeel over de (on)aanvaardbaarheid van secundaire aansprakelijkheden, althans de terughoudendheid die bij de aanname daarvan betracht dient te worden, ${ }^{53}$ in plaats van dat zij argumenten aandraagt die in dit specifieke geval de afwijzing van de aansprakelijkheid rechtvaardigen. Of dit ook echt het geval is, wordt aan het zicht onttrokken door de moeilijk te volgen redeneringen over de relativiteit. Ik sluit dan ook aan bij de opmerking van Schutgens in zijn annotatie bij het onderhavige vonnis, te weten dat - mocht de rechter aansprakelijkheid categorisch bij de primaire veroorzaker willen leggen - het beter is als hij dat ronduit zou overwegen. ${ }^{54}$

\subsection{Het arrest van het hof: gerechtigheid troef}

Het moge duidelijk zijn dat het hof met zijn arrest tegemoetkomt aan de kritieken op de toepassing van het relativiteitsvereiste, zoals hiervoor besproken, en dat het arrest daarom naar mijn verwachting in de (eerder kritische) literatuur positief zal worden ontvangen. Zo merkt Hulst in zijn recente bijdrage op dat 'het grote winst is dat het hof de verantwoordelijkheid precies daar legt waar hij thuishoort' en dat dit arrest van het hof 'de burger heeft laten zien dat recht ertoe doet'. ${ }^{55}$ Ondanks de kritische (meer dogmatische) kanttekeningen merken ook Schutgens en Van der Werf op dat het arrest meer aanspreekt

51. Zie ook Meijer 2015, p. 79.

52. Zie hierover ook Tjong Tjin Tai 2006, p. 69-71 en zie ook eerder Maes 2016, p. 8 .

53. Zie eerder ook Maes 2016, par. 4-5 en Maes 2017b, p. 45-50.

54. Schutgens 2015 , ov. 5.

55. E.H. Hulst, Recht doet ertoe, zo niet bestuursrechtelijk, dan toch civielrechtelijk, TGMA 2018, p. 25 en 27. 
dan het vonnis van de rechtbank. ${ }^{56}$ Laat ik daaraan opvolging geven door op te merken dat het arrest van het hof in mijn ogen meer recht doet aan de ter tafel liggende rechtsvragen met betrekking tot de relativiteit dan het eerdere vonnis van de rechtbank deed.

Dat zit in de eerste plaats - ik neig te zeggen: natuurlijk - in sec de uitkomst van het positieve relativiteitsoordeel zelf, waarbij door het hof in r.o. 8.3-8.4 de juiste (materiële) geschonden norm voorop wordt gesteld (kort gezegd: de politie had het wapenverlof, gezien de weigeringsgronden, niet mogen afgeven), in plaats van enkel aan de (on)zorgvuldige besluitvorming te refereren. Zoals Franssen en Van Tilborg terecht opmerkten, zo besprak ik in paragraaf 5.1.1, heeft deze formulering van de geschonden norm consequenties voor het relativiteitsoordeel. Het hof 'herstelt' de omissie van de rechtbank op dit punt in heldere en bondige overwegingen.

In de tweede plaats toont het hof - alhoewel impliciet - meer erkenning voor het wezen van secundaire aansprakelijkheid en de daarin besloten liggende gradatie van onvoorzienbaarheid, zoals door mij toegelicht in paragraaf 5.1.2.

Zo acht het hof in r.o. 7.13 voor de kenbaarheid van het specifieke gevaar van belang dat 'niet buiten twijfel kan worden geacht of Tristan een gevaar vormt voor zichzelf en het voorhanden hebben van vuurwapens gezien zijn psychische gesteldheid aan hem kan worden toevertrouwd'. Daarmee veegt het hof het verweer van de politie van tafel dat, zonder nadere gegevens, niet zonder meer gezegd is dat iemand twee jaar na een gedwongen opname nog steeds in dezelfde psychische toestand verkeert (en het dus maar de vraag is of deze informatie twijfel bij de politie had moeten oproepen in het kader van de verlofverlening). Het hof keert in zijn antwoord op dit verweer de redenering in feite om door 'het niet buiten twijfel kunnen stellen' van het gevaar bij de beoordeling van de normschending voorop te stellen, in plaats van 'het zonder twijfel (zeker) weten' daarbij van doorslaggevend belang te achten.

In het verlengde daarvan (en specifieker) overweegt het hof vervolgens in r.o. 9.4 - in navolging van de (her)definiëring van de geschonden norm - dat de aard van de norm (naar mijn idee: een veiligheidsnorm) meebrengt dat aan de voorzienbaarheid van de schade minder hoge eisen hoeven te worden gesteld. Daarmee sluit het hof niet alleen aan bij de deelre-

56. Schutgens \& Van der Werf 2018; welke conclusie de auteurs in randnr. 1 trekken, óndanks dat de ruimhartige toepassing van het relativiteitsvereiste wat hen betreft op gespannen voet staat met de jurisprudentie van de Hoge Raad, zoals het Duwbak Linda-arrest. Een categorische afwijzing van aansprakelijkheid in deze zaak wordt door de auteurs immers onbevredigend genoemd. De kritische noot wordt overigens later in de bijdrage (in randnr. 7) genuanceerd door op te merken dat het toetsingskader uit dat arrest onvoldoende dwingend is om die conclusie met volledige zekerheid te trekken. gels van Brunner, ${ }^{57}$ maar stelt hij in mijn ogen ook redelijke eisen aan de speculatieve, secundaire zorgplicht van de politie. Zodoende komt het hof tegemoet aan het 'gegeven' dat de hier aangesproken secundaire partij (de politie) - om de simpele reden dat de schade direct door de voor haar onvoorspelbare primaire schadeveroorzaker (Tristan) wordt veroorzaakt - op voorhand per definitie relatief slecht kon inschatten tot welke specifieke gevaren haar zorgplicht precies strekte. ${ }^{58}$

Met deze voorzienbaarheidsmaatstaf in de hand en met een verwijzing naar buitenlandse schietincidenten met behulp van (legale) vuurwapens oordeelt het hof in r.o. 9.6, dat:

'niet kan worden gezegd dat voor de politie ten tijde van de verlening van het verlof onvoorzienbaar was dat Tristan vuurwapen(s) tegen anderen zou gaan gebruiken. Integendeel, dat was toen in zekere zin wel te voorzien.'

Ook hier keert het hof het toetsingskader als het ware om, door 'niet onvoorzienbaar' in plaats van 'voorzienbaar' als vertrekpunt te hanteren.

Tot slot: het hof merkt in r.o. 9.8 - zonder nadere toelichting - op dat voor de aansprakelijkheid van de politie niet van belang is dat appellanten 'tot een onbepaalde groep behoorden'. Enige motivering had hier wat mij betreft gepast, maar dat maakt de opmerking, vanuit het in paragraaf 5.1 .2 besproken 'wezen' van de secundaire aansprakelijkheid, niet minder terecht. Zoals toegelicht, zal de secundaire partij (de politie), daar waar de schade direct door de primaire partij (Tristan) in het leven is geroepen, op voorhand vrijwel per definitie slecht kunnen inschatten tot welke concrete groep zorgontvangers haar zorgplicht precies strekt, en is dat op zichzelf geen goede reden voor afwijzing ervan. ${ }^{59}$ Of dit ook de gedachtegang van het hof is geweest, of op enigerlei wijze gewicht in de schaal heeft gelegd, is bij gebrek aan motivering niet vast te stellen.

\section{De voor vergoeding in aanmerking komende schade}

\subsection{Algemeen kader}

De rechtbank kwam vanwege de afwijzing van de aansprakelijkheid aan de vraag naar de voor vergoeding in aanmerking komende schade - welke schade staat ex artikel 6:98 BW in redelijk verband tot de normschending? - niet toe. Het hof komt hier vanwege zijn toewijzende arrest wél aan toe, en maakt daarbij onderscheid tussen letsel- en overlijdensschade en overige schades (zaakschade en zuivere vermogensschade). De vraag die resteert is of deze keuze juist is.

57. Brunner 1981, p. 21 e.v. en p. 233 e.v. en Asser/Hartkamp \& Sieburgh 6-II $2017 / 63$.

58. En tot welke concrete groep zorgontvangers. Zie over afgeleide zorgplichten Tjong Tjin Tai 2006, p. 69. Zie ook eerder Maes 2016 en Maes 2017 a.

59. Zie nader par. 5.1.2. Zie over afgeleide zorgplichten Tjong Tjin Tai 2006, p. 69. Zie ook eerder Maes 2016 en Maes 2017a. 
Laat ik eerst de principiële vraag beantwoorden of het hof, los van de feiten en omstandigheden van de onderhavige zaak, bij toepassing van artikel 6:98 BW een 'knip' kon maken in de voor vergoeding in aanmerking komende schade. Dat antwoord luidt positief. ${ }^{60} \mathrm{Bij}$ toepassing van artikel 6:98 BW moet immers worden bepaald welke schadeposten in voldoende verband staan met de gebeurtenis waarvoor aansprakelijkheid is aangenomen. Onder het oude recht werd voor deze toerekeningsvraag het criterium van de voorzienbaarheid gebruikt. ${ }^{61}$ Naar het huidige recht ziet de toerekeningsvraag echter niet meer op één causaliteitscriterium, maar komt het neer op een afweging van relevante gezichtspunten, zoals de aard van de aansprakelijkheid, de aard van de schade, de aard van de gedraging én de voorzienbaarheid. ${ }^{62}$ Hierbij wordt gedoeld op - zo noemde ik al eerder - de deelregels van Brunner, waar ook het hof in r.o. 9.4 aan refereert. ${ }^{63}$

Deze deelregels laten een tweedeling in de voor vergoeding in aanmerking komende schades toe. Zo is in de eerste plaats de aard van de schade relevant bij de beoordeling van de vraag of de schadeposten in voldoende verband staan met de gebeurtenis waarvoor aansprakelijkheid is aangenomen: overlijdens- en letselschade worden eerder aan de aansprakelijke partij toegerekend dan zaakschade, zaakschade weer eerder dan zuivere vermogensschade en geleden verlies eerder dan gederfde winst. ${ }^{64}$ In lijn met deze regel kán het dan dus ook gerechtvaardigd zijn overlijdens- en letselschade wel aan de politie toe te rekenen, maar zaak- en zuivere vermogensschade niet. Sterker nog: het is in dit licht eerder gerechtvaardigd om wél letselen overlijdensschade toe te kennen en zaak- en zuivere vermogensschade niet, dan andersom. Ook de voorzienbaarheid van de schade als relevant criterium bij de toerekening kan een tweedeling rechtvaardigen. Betoogd moet dan worden dat letsel- en overlijdensschade (meer) redelijkerwijze te verwachten gevolgen van een gebeurtenis als het schietincident betreffen dan zaakschade en zuivere vermogensschade.

In de rechtspraak is het dan ook niet ongebruikelijk om deze tweedeling te maken en letsel- en overlijdensschade sneller toe

60. Waarbij ik wijs op het betoog van Verheij, dat hetzelfde effect (bepaalde schadeposten wel voor vergoeding in aanmerking laten komen en bepaalde schadeposten niet) gerealiseerd kan worden via het relativiteitsvereiste van art. 6:163 BW. Wat hem betreft zijn de relativiteit en deze causaliteit dus in zekere zin inwisselbare perspectieven, waarbij de relativiteit vanuit de norm vooruitkijkt of deze de strekking heeft te beschermen tegen de schade zoals deze is geleden, terwijl de juridische causaliteit terugkijkt vanuit de schade en de vraag stelt of deze nog in redelijkheid valt toe te rekenen aan de onrechtmatige gedraging. Dat sprake is van overlap is dus niet vreemd en het is evenmin vreemd dat pogingen zijn gedaan om van één van beide leerstukken af te komen, aldus Verheij. Zie nader over deze verhouding tussen relativiteit (art. 6:163 BW) en juridische causaliteit (art. 6:98 BW) A.J. Verheij, De Hoge Raad en de relativiteit. Voorstel voor een hanteerbare toets, NTBR 2014/12, afl. 3, p. 95-104.

61. Oosterveen \& Frenk/Lindenbergh, in: T\&C Burgerlijk Wetboek, art. 6:98 BW, aant. 5.

62. Parl. Gesch. Boek 6 BW, p. 345.

63. Brunner 1981, p. 21 e.v. en p. 233 e.v. en Asser/Hartkamp \& Sieburgh 6-II $2017 / 63$.

64. Asser/Hartkamp \& Sieburgh 6-II 2013/66 en 68 en Boonekamp, in: GS Schadevergoeding 2017, art. 6:98 BW, aant. 4.5.1. te rekenen. ${ }^{65}$ Daarbij dient te worden bedacht dat overtredingen van verkeers- en veiligheidsnormen in het algemeen een ruime toerekening gebieden; bij de schending van andere normen geldt vaak een beperktere toerekening. ${ }^{66}$ De toerekening bij schending van deze normen kan soms zo ver gaan dat ook letsel dat buiten de lijn der verwachting ligt, wordt toegerekend. ${ }^{67}$

\subsection{Onderscheid schadeposten in het onderhavige geval}

Duidelijk is dus dat de splitsing in voor vergoeding in aanmerking komende schades in abstracto juridisch-dogmatisch te rechtvaardigen valt. Maar valt het ook in de onderhavige zaak te rechtvaardigen? Volgens Franssen en Van Tilborg wel, althans dat leid ik af uit hun voor dit arrest geschreven bijdrage waarin zij het onderscheid in de te vergoeden schades (ook) maken. Zo merken de auteurs op dat er wat hen betreft 'goede argumenten bestaan om aan te nemen dat de geschonden norm (specifiek) tot doel heeft om te beschermen tegen de schade zoals die door eisers is geleden, voor zover het schade als gevolg van lichamelijk letsel of overlijden betreft'. Ter toelichting wordt vervolgens in een voetnoot opgemerkt:

'Wij betwijfelen of hetzelfde antwoord geldt voor de omzetschade die als gevolg van het schietincident is geleden door de winkeliers. Er bestaat immers geen enkele aanwijzing in de totstandkomingsgeschiedenis van de WWM of de Vuurwapenwet 1919 voor de conclusie dat de wetgever met de WWM ook beoogde dat soort schade te voorkomen. ${ }^{68}$

In gelijke zin merkt Di Bella op dat het 'heel vaak zo zal zijn' dat in de parlementaire geschiedenis wordt gezwegen over vermogensbelangen van derden (waarbij zij lijkt te doelen op letselschade, zo leid ik af uit de alinea daarvoor). Een wetsbepaling wordt immers gemakkt met het oog op een publiek belang en/of ter bescherming tegen een (maatschappelijk) gevaar, aldus Di Bella. Zij merkt vervolgens op:

65. HR 13 januari 1995, ECLI:NL:HR:1995:ZC1611 (De Heel/Korver); HR 18 maart 2005, ECLI:NL:PHR:2005:AR5214 (Baby Kelly); HR 11 juni 2010, ECLI:NL:HR:2010:BM0895 (Sulman/Reaal). Zie ook Di Bella 2016, p. 130 met een verwijzing naar HR 17 november 1978, NJ 1979/316 m.nt. G.J. Scholten; HR 2 maart 2001, NJ 2001/649 m.nt. J.B.M. Vranken en F.C.B. van Wijmen; HR 22 februari 2002, NJ 2002/240 m.nt. J.B.M. Vranken; en bij art. 6:174 BW: HR 8 oktober 2010, NJ 2011/465 m.nt. T. Hartlief (Hangmat).

66. C. Holthuijsen-van der Kop, De redelijke toerekening van de deelregels anno 2015: een update, WPNR 2015/7065, p. 522. Zie hierover ook de blog van T. Hartlief, Een vak apart, NJB 2014/2109, afl. 41, p. 2917.

67. HR 8 februari 1985, ECLI:NL:PHR:1985:AG4961 (Renteneurose); HR 25 november 2005, ECLI:NL:HR:2005:AU 4042 (Eurosportief).

68. Franssen \& Van Tilborg 2015, p. 62, voetnoot 41. Genuanceerder komt dit onderwerp echter in het vervolg van de bijdrage ter sprake, waar de auteurs de vraag stellen in hoeverre uit het zwijgen van de wetgever in de totstandkomingsgeschiedenis over de vergoeding van vermogensschade c.q. de bescherming van vermogensbelangen kan worden afgeleid dat deze schade dus niet voor vergoeding in aanmerking komt. De auteurs blijven echter bij hun stelling dat goed betoogd kan worden dat de wetsgeschiedenis mede tot doel heeft om schade in de vorm van letsel als gevolg van (te voorzien) misbruik van een wapen te voorkomen. 
'in de toelichting wordt meestal niet gerept over vermogensbelangen, omdat de bepaling daar niet over gaat. Het ligt daarom meer voor de hand dat de wetgever gewoon niet aan het schadeaspect heeft gedacht. ${ }^{69}$

Ook Di Bella concludeert vervolgens dat vergoeding in de onderhavige zaak van 'in ieder geval een gedeelte van de letselschade op zijn plaats zou zijn'.70

Ik kan dat standpunt volgen en lees dat ook in de overwegingen in de parlementaire geschiedenis van de CWM en WWM, te weten dat wapens en munitie 'een potentieel ernstige bedreiging voor de veiligheid in de samenleving vormen indien zij in handen komen van personen die onvoldoende betrouwbaar zijn om wapens en munitie voorhanden te hebben', en dat van illegaal wapenbezit 'reeds een ernstige bedreiging voor het leven en de vrijheid van personen uitgaat'. ${ }^{71}$ Het is wat mij betreft goed verdedigbaar dat met veiligheid in de context van wapens en munitie door de wetgever in de eerste plaats aan de fysieke veiligheid gedacht is. Daarin voel ik mij gesterkt door de hiervoor aangehaalde jurisprudentie, waaruit volgt dat het bij de ruime toerekening van letsel- en overlijdensschade gaat om overtredingen van verkeers- en veiligheidsnormen, zoals in de onderhavige zaak ook het geval is. ${ }^{72}$ Of, in de woorden van Boonekamp:

'De ruime toerekening bij overtreding van verkeers- en veiligheidsnormen berust ook daarop dat die normen juist de strekking hebben te beschermen tegen dood en letsel. ${ }^{.73}$

Gelijkgestemden vind ik daarbij in Schutgens en Giesen. Eerstgenoemde merkt in zijn annotatie bij de uitspraak van de rechtbank in de onderhavige zaak op dat 'de WWM-bevoegdheden er bij uitstek op gericht zijn om te voorkómen dat misdadigers en verwarde personen dit soort personenschade veroorzaken'. ${ }^{74}$ Giesen merkt in zijn bijdrage (nog) stelliger op: 'de bescherming van onze veiligheid kan niets anders betekenen dan dat het ook de bescherming van onze vermogensbelangen (die onlosmakelijk aan letsel verbonden zijn) omvat'. ${ }^{\text {' }}$ In de bijdrage van Giesen valt bovendien op dat hij - in zijn betoog dat aansprakelijkheid wél had moeten volgen - het woord 'letsel' tussen haakjes voor de schade plaatst. Ook Giesen lijkt dus in elk geval niet overtuigd van het feit dat álle

69. Di Bella 2016, p. 130

70. Di Bella 2016, p. 132

71. Kamerstukken II $1979 / 80,14413$, 5, p. 2, en r.o. 3.7, 5.11 en 5.41 van het vonnis van de rechtbank.

72. Boonekamp 2017, aant. 4.5.1.

73. R.J.B. Boonekamp, Met gezond verstand en rechtsgevoel, in: J. Spier \& W.A.M. van Schendel (red.), Schadevergoeding: een eeuw later, Deventer: Kluwer 2002, p. 42

74. Schutgens 2015 , ov. 7 , alhoewel hij in zijn annotatie bij het arrest van het hof wel ook een kritische noot plaatst over de vraag of het hof het Duwbak Linda-arrest wel goed toepast. Zie hierover Schutgens \& Van der Werf 2018, p. 24.

75. Giesen 2015, p. 278. schadecomponenten voor vergoeding in aanmerking dienen te komen, zo leid ik daaruit af. ${ }^{76}$

Een en ander brengt mij tot de conclusie dat de tweedeling die het hof hier maakt - wel vergoeding van letsel- en overlijdensschade, geen vergoeding van andere schades (zaakschade en zuivere vermogensschade) - in het licht van de rechtspraak en literatuur in abstracto, maar ook in deze kwestie in het bijzonder te verdedigen valt. Het gaat in kwestie om de schending van een veiligheidsnorm, die - vanwege het wezen van een veiligheidsnorm, maar helemaal gezien de specifieke overwegingen in de parlementaire geschiedenis - tot doel heeft het leven en de vrijheid van personen te beschermen, en daarmee dood en letsel te voorkomen. Letsel- en overlijdensschade betreffen daarmee gevolgen van het misbruik van wapens en munitie die naar ervaringsregels waarschijnlijker zijn, en daarmee meer voorzienbaar voor de politie dan (zeker) zuivere vermogensschade en (in mindere mate) zaakschade. Betrek daarbij tot slot het adagium van Brunner, dat overlijdens- en letselschade al principieel en naar hun aard eerder voor toerekening in aanmerking komen dan zuivere vermogensschade en zaakschade, en mijn conclusie luidt dat het hof met het gemaakte onderscheid een verdedigbare keuze maakt.

Desondanks had het hof deze 'keuze' in zijn arrest met wat meer woorden kunnen en misschien wel moeten omkleden. Onverminderd het voorgaande, geldt immers dat ten aanzien van de gevorderde zaakschade wat mij betreft óók anders betoogd kan worden. Als personenschade immers een voorzienbaar gevolg is van een schietpartij, kan dan niet in gelijke zin gesteld worden dat ook voorzienbaar is dat daarbij eigendommen (zoals in casu winkels) beschadigd raken? In de regel zullen schietincidenten, naast personenschade, toch ook tot de beschadiging van zich daar bevindende zaken leiden, en zal die schade daarom dus net zo goed voorzienbaar zijn? Hulst merkt in lijn met deze gedachtegang op dat - alhoewel uit de Kamerstukken inderdaad blijkt dat het gaat om bescherming van personen - 'feit blijft dat de kans bij iedereen bekend is dat je met een schot ook andere schade toebrengt, zoals kogelgaten in muren'. Dit geldt, zoals gezegd, in mijn ogen met name ten aanzien van zaakschade en minder voor wat betreft de zuivere vermogensschade: deze directe schade aan eigendommen is - en in lijn met de deelregels van Brunner, waarbij zaakschade in het algemeen eerder toegerekend wordt dan zuivere vermogensschade - op haar beurt weer een meer direct gevolg en daarmee meer voorzienbaar dan (bijvoorbeeld) een schadepost als gederfde winst (als mogelijk gevolg van die beschadiging). Omdat het antwoord op de redelijke toerekeningsvraag dus geen wet van Meden en Perzen is en ruimte laat voor discussie, zou een meer uitvoerige motivering op dit punt het arrest hebben gepast, zo merkt ook Hulst op in zijn

\footnotetext{
76. Ik refereer aan de opmerking: 'Hoe kan uit dit type overwegingen iets anders volgen dan dat de WWM nu juist wél strekt ter voorkoming van (letsel)schade als gevolg van misbruik van wapens waarvoor verlof is verleend en de bescherming van burgers daartegen?' (Giesen 2015, p. 277).
} 
bijdrage. ${ }^{77}$ In het zowel door de politie als door de slachtoffers met zaakschade en zuivere vermogensschade ingestelde cassatieberoep zal deze motivering naar mijn verwachting dan ook onderwerp zijn.

\section{Conclusie}

Nog geen halfjaar geleden vroeg ik mij naar aanleiding van de afwijzing van de aansprakelijkheid van de ouders van Tristan - welke uitspraak van de rechtbank wat mij betreft overigens wél goed te volgen was - hardop af of het in dit artikel centraal staande hoger beroep eisers soelaas zou bieden. ${ }^{78}$ Het antwoord luidt bevestigend, zo leert het onderhavige arrest.

De rechtbank koos voor terughoudendheid in een kwestie die alleen maar verliezers kent, met naar mijn inschatting in haar achterhoofd de angst voor een verder aanwassend c.q. onhoudbaar aantal (secundaire) aansprakelijkheidsclaims, ook wel aangeduid als 'Amerikaanse toestanden' in eigen land. ${ }^{79}$ Het hof heeft - wellicht onder druk, maar (ook) in alle (juridischdogmatische) logica - de deur van de relativiteit wél opengezet, nadat deze door de rechtbank angstvallig dicht werd gehouden. Daarmee herstelt het hof een steek die de rechtbank liet vallen. Dat ook het hof de (aansprakelijkheids)teugels niet helemaal laat vieren, volgt uit de tweedeling die het hof aan de hand van artikel 6:98 BW in de voor vergoeding in aanmerking komende schades maakt. Letsel- en overlijdensschade dienen door de politie wel te worden vergoed, andere (vermogens)schade niet. In zoverre blijft de geest dus in de fles.

77. Hulst 2018, p. 26

78. Maes 2017a.

79. Ik laat even terzijde of deze aanduiding überhaupt terecht is. Zie eerder Maes 2016, par. 2.2. Meer in het algemeen over deze tendens: A.T. Bolt \& J. Spier, De uitdijende reikwijdte van de aansprakelijkheid uit onrechtmatige daad, Zwolle: W.E.J. Tjeenk Willink 1996, p. 392; T. Hartlief, Ieder draagt zijn eigen schade (oratie Leiden), Deventer: Kluwer 1997, p. 13; A.L.M. Keirse, Nieuwe risico's: wie is er bang voor de magnetron? NJB 2007/82, in het bijzonder par. 3.3; Rijnhout e.a. 2013, par. 2 en 4.3; Giesen 2014, p. 81-115. 